\title{
Recent advances in the systemic management of non-clear cell renal cell carcinoma: a review article
}

\author{
Soumish Sengupta ${ }^{1 *}$, Supriya Basu ${ }^{1}$, Kadambari Ghosh ${ }^{2}$
}

${ }^{1}$ Department of Urology, R. G. Kar Medical College and Hospital, Kolkata, West Bengal, India
${ }^{2}$ Department of Radiology, Basu's Clinic Healthcare Private Limited, Siliguri, West Bengal, India

Received: 05 July 2020

Accepted: 04 August 2020

\section{*Correspondence:}

Dr. Soumish Sengupta,

E-mail: soumishuro@gmail.com

Copyright: (C) the author(s), publisher and licensee Medip Academy. This is an open-access article distributed under the terms of the Creative Commons Attribution Non-Commercial License, which permits unrestricted non-commercial use, distribution, and reproduction in any medium, provided the original work is properly cited.

\begin{abstract}
Non-clear cell renal cell carcinoma (nccRCC) is not as common as clear cell renal cell carcinoma (ccRcc). But then it is not uncommon in regular urological practice. It usually carries a grave prognosis. Authors need to converse ourselves with National comprehensive cancer network (NCCN) categories for evidence and we need to converse as well with NCCN categories for preferences. 'Preferred intervention' is based on superior efficacy, safety and evidence and when appropriate, affordability. 'Other recommended interventions' are somewhat less efficacious, more toxic, or based on less mature data or significantly less affordable for similar outcomes. 'Useful in certain circumstances' are interventions that may be used for a selected patient population. Clinical trials for targeted agents are mainly directed at ccRCC because of its high prevalence. According to the NCCN panel, enrolment in clinical trials is the preferred strategy for nccRCC. Outcomes of patients with nccRCC have improved with the introduction of targeted therapy. Precise pathological diagnosis of the types of nccRCC by immunohistochemical analysis is mandatory. This enables specific treatments for individual nccRCC. Currently TKIs are the drug of choice (both first and second line) for metastatic papillary RCC. Both TKIs and mTOR inhibitors are effective against chromophobe RCC. Platinum based chemotherapy should be used for metastatic CDC. Further evidence is required for management of nccRCC.
\end{abstract}

Keywords: Chromophobe, Consensus, Immunohistochemical, Intervention, Non-clear cell renal cell carcinoma, Prognosis, Targeted therapy

\section{INTRODUCTION}

Though non-clear cell renal cell carcinoma (nccRCC) is not as common as clear cell renal cell carcinoma (ccRcc) in incidence yet it demands authors utmost attention. It is not uncommon in regular urological our utmost attention practice and usually carries a dismal prognosis. We need to converse ourselves with National comprehensive cancer network (NCCN) categories for evidence and consensus as well with NCCN categories for preferences.

Category 1 implies high level evidence with uniform consensus that intervention is appropriate. Both category $2 \mathrm{~A}$ and $2 \mathrm{~B}$ have low level evidence but only the former has uniform consensus that intervention is appropriate. category 3 is based on any level of evidence and has a major Category $3 \mathrm{NCCN}$ disagreement that the intervention is appropriate. 'Preferred intervention' is based on superior efficacy, safety and evidence and when appropriate, affordability. 'Other recommended interventions' are somewhat less efficacious, more toxic, or based on less mature data or significantly less affordable for similar outcomes. 'Useful in Certain circumstances' are interventions that may be used for a selected patient population.

Clinical trials for targeted agents are mainly directed at ccRCC because of its high prevalence. According to the NCCN panel, enrolment in clinical trials is the preferred strategy for nccRCC. There are randomized phase II 
studies showing activity of systemic therapy in patients with nccRCC but response rate is less with nccRCC as compared to ccRCC.

Table 1: 2016 WHO classification of renal cell tumors.

\begin{tabular}{|c|c|}
\hline Sr. No. & $\begin{array}{l}2016 \text { WHO classification of renal cell } \\
\text { tumors }\end{array}$ \\
\hline 1. & Clear cell RCC \\
\hline 2. & $\begin{array}{l}\text { Multilocular cystic renal cell neoplasm of } \\
\text { low malignant potential }\end{array}$ \\
\hline 3. & Papillary RCC \\
\hline 4. & $\begin{array}{l}\text { Heriditary leiomyomatosis and RCC- } \\
\text { associated RCC }\end{array}$ \\
\hline 5. & Chromophobe RCC \\
\hline 6. & Collecting duct carcinoma \\
\hline 7. & Renal medullary carcinoma \\
\hline 8. & MiT family translocation RCC \\
\hline 9. & Succinate dehydrogenase-deficient RCC \\
\hline 10. & Mutinous tubular and spindle cell carcinoma \\
\hline 11. & Tubulocystic RCC \\
\hline 12. & Acquired cystic disease-associated RCC \\
\hline 13. & Clear cell papillary RCC \\
\hline 14. & RCC (unclassified) \\
\hline 15. & Papillary adenoma \\
\hline 16. & Oncocytoma \\
\hline
\end{tabular}

\section{SUNITINIB IN NON-CLEAR CELL RENAL CELL CARCINOMA}

There are two phase II clinical trials, expanded access trials and retrospective analysis supports clinical activity. In a study of 31 patients, 36\% (95\% CI:19\%-52\%) overall response rate (ORR) with a median progression free survival (PFS) of 6.4 months. ${ }^{1}$ In another study of 53 patients with sunitinib or sorafenib with tumour type papillary and chromophobe renal cell carcinoma showed ORR of $23 \%$ and median PFS of 10.6 months. $^{2}$

The ASPEN trial is a phase II study of 108 previously untreated patients randomly assigned to sunitinib group and everolimus group. The primary end points, median PFS (good risk patient), median PFS (intermediate risk patient), median PFS (poor risk patient) were 8.3 months versus 5.6 months, 14 months versus 5.7 months, 6.5 months versus 4.9 months and 4 months versus 6.1 months in sunitinib versus everolimus group respectively. ${ }^{3}$

The ESPN trial included 68 patients of metastatic nccRCC . They received first line sunitinib or everolimus. The median PFS, final overall survival (OS) and median OS (with no sarcomatoid feature) was 6.1 months versus 4.1 months, 16.2 months versus 14.9 months, 31.6 months versus 10.5 months in sunitinib and everolimus group respectively. The final OS was not statistically significant.
In nccRCC, Tyrosine Kinase inhibitors (TKI) reduced the risk of progression compared to mammalian targets of rapamycin (mTOR) inhibitors. ${ }^{5}$ Sunitinib reduced the risk of progression compared to everolimus in the first line setting. (no significant differences in OS and ORR). Sunitinib is listed as a category $2 \mathrm{~A}$ preferred option for treatment naïve patients with stage IV nccRcc.

\section{CABOZANTINIB IN NON-CLEAR CELL RENAL CELL CARCINOMA}

There are no prospective trials. A retrospective study involving 30 patients with nccRCC showed median PFS of 8.6 months, median OS of 25.4 months and ORR of $14.3 \%$ among 28 patients with measurable disease. ${ }^{6}$

It is categorized as $2 \mathrm{~A}$ as per $\mathrm{NCCN}$ panel and as per NCCN preference-'other recommended option' for relapsed or stage IV nccRCC.

\section{EVEROLIMUS IN NON-CLEAR CELL RENAL CELL CARCINOMA}

Seventy-five subjects were included in the RAD001 expanded access clinical trials (REACT). ${ }^{7}$ The median duration of treatment was 12.14 weeks in metastatic nccRCC. The ORR was $1.7 \%$ and rate of stable disease was $51.6 \%$.

The median duration of treatment in the overall REACT trial was 14.0 weeks with ORR of $1.3 \%$ and rate of stable disease of $49.3 \%$. The adverse events in the group were anemia (9.3\%), pleural effusion $(9.3 \%)$, dyspnoea, fatigue, asthenia, stomatitis and pneumonitis.

A phase II study of 49 previously treated patients with sunitinib or sorafenib were given $10 \mathrm{mg}$ everolimus orally until disease progression or unacceptable side effects were seen. ${ }^{8}$ Histology distribution were papillary (subjects[n]-29), chromophobe (n-8), collecting duct (n2 ), sarcomatoid (n-4) and unclassified (n-6). The ORR was $10.2 \%$ (all responses were partial), 25 patients had stable disease $(51 \%)$ and 16 patients progressed $(32.7 \%)$. The adverse effects were anemia $(10.2 \%)$, hyperglycemia $(8.2 \%)$, infection $(6.1 \%)$ and pneumonitis $(4.1 \%)$.

RAPTOR phase II trials of previously untreated patients of advanced papillary RCC were given $10 \mathrm{mg}$ everolimus daily. ${ }^{9}$ The median PFS and median OS was 7.9 months versus 5.1 months and 28 months versus 24.2 months respectively in type I papillary RCC and type II papillary RCC groups. As per NCCN panel it is category $2 \mathrm{~A}$ drug with 'other recommended option for nccRCC. Lenvatinib plus everolimus was also categorized as $2 \mathrm{~A}$ and 'useful under certain circumstances' for treatment of nccRCC. 


\section{PAZOPANIB AND AXITINIB IN NON-CLEAR CELL RENAL CELL CARCINOMA}

No clinical benefits have been established yet. A phase II trial with pazopanib in 28 subjects of locally advanced or metastatic nccRCC (excluding collecting duct and sarcomatoid type) showed confirmed partial response in 8 patients with ORR of $28 \% .^{10}$

Another phase II trial of axitinib included 40 patients with recurrent or metastatic nccRCC who failed treatment with temsirolimus. The median PFS was 7.4 months and ORR was $37.5 \% .^{11}$

Both pazopanib and axitinib are category $2 \mathrm{~A}$ drugs and 'useful under certain circumstances' for relapsed or unresectable stage IV nccRCC.

\section{BEVACIZUMAB MONOTHERAPY IN NON- CLEAR CELL RENAL CELL CARCINOMA}

A small phase II trial of 5 patients was undertaken. The subjects received bevacizumab monotherapy in three patients following nephrectomy (median PFS of 25 months, 15 months and 11 months), one patient following resection of liver metastasis (median PFS of 10 months) and one patient with prior treatment with temsirolimus (median PFS of 6 months). It showed grade 1-2 toxicities especially hypertension, creatinine elevation and proteinuria. It is listed in category $2 \mathrm{~A}$ as per NCCN panel; as a therapeutic option for nccRCC. ${ }^{12}$ The study was closed early due to such a small number of subjects.

\section{ERLOTINIB IN NON-CLEAR CELL RENAL CELL CARCINOMA}

It is an oral epidermal growth factor receptor (EGFR) TKI. Fifty-two subjects with advanced papillary RCC were given once daily dosage. ORR was $11 \%$ (5 of 45 subjects). Disease control rate, defined as stable disease for 6 weeks or confirmed partial response or complete response under response evaluation criteria in solid tumor (RECIST), was $64 \%$. Median OS was 27 months. ${ }^{13}$ It is listed under NCCN panel category 2A; 'useful under certain circumstances' for first line therapy for patients with relapsed or medically unresectable stage IV nccRCC.

\section{NIVOLUMAB IN NON-CLEAR CELL RENAL CELL CARCINOMA}

Two retrospective studies were conducted where patients were administered Nivolumab (Human igG4 monoclonal $\mathrm{Ab}$ that blocks PD-I). The first study involved 35 subjects with metastatic nccRCC. Partial response was noted in $20 \%$. Stable disease in $29 \%$ and the median PFS was 3.5 months. ${ }^{14}$ The second study included 43 patients of metastatic nccRCC who received nivolumab showed an objective response of $19 \%$. It is a category $2 \mathrm{~A}$ drug as per
NCCN panel for selected patients with advanced nccRCC. ${ }^{15}$

\section{BEVACIZUMAB AND ERLOTINIB FOR ADVANCED PAPILLARY RCC INCLUDING HEREDITARY LEIOMYOMATOSIS AND RCC}

Hereditary leiomyomatosis and RCC (HLRCC) is associated with an aggressive form of papillary kidney cancer along with uterine leiomyomas and skin involvement. A phase II trial included 41 patients with advanced papillary RCC. Out of 41 patients, 19 had received at least one prior line of therapy. They were treated with bevacizumab and erlotinib. ${ }^{16}$

The HLRCC group showed a median PFS of 24.2 months and ORR of $60 \%$. Sporadic cases showed median PFS of 7.4 months and ORR of $29 \%$.

This combination drug has category $2 \mathrm{~A}$ recommendation for advanced RCC with papillary histology including HLRCC.

\section{BEVACIZUMAB WITH EVEROLIMUS FOR ADVANCED NON CLEAR CELL RENAL CELL CARCINOMA}

A phase II trial comprising 35 patients with advanced nccRCC were administered a combination of bevacizumab and everolimus.

Median PFS was 11 months. OS and ORR were 18.5 months and 29\% respectively. There was higher PFS with papillary and chromophobe elements. The adverse effects include hyperglycemia (11\%), hypertriglyceridemia (14\%), lymphoma (20\%), hypertension (29\%) and proteinuria $(18 \%){ }^{17}$

\section{TEMSIROLIMUS FOR NON-CLEAR CELL RENAL CELL CARCINOMA}

A phase III trial, predominantly of papillary RCC, was treated with temsirolimus or interferon-alpha (IFN- $\alpha$ ). The median OS was 11.6 months and 4.3 months in the former and latter group respectively. ${ }^{18,19}$

Inspired by the groups study result, a case report of metastatic chromophobe RCC refractory to treatment with sunitinib achieved durable clinical response lasting 20 months. $^{20}$ Temsirolimus has category 1 recommendation for nccRCC with poor prognostic features (according to MSKCC risk criteria). It has category $2 \mathrm{~A}$ recommendation for other prognostic nccRCC.

\section{CHEMOTHERAPY FOR METASTATIC RCC}

Treatment of sarcomatoid and nccRCC remains a challenge. Sarcomatoid variant is an aggressive form of RCC that can occur in any histologic subtype. 
Gemcitabine with doxorubicin/capecitabine has shown activity in nccRCC or ccRCC with sarcomatoid features. Bevacizumab with capecitabine and gemcitabine has shown a low response rate in a phase II trial of patients with sarcomatoid RCC. Trial is also undergoing with sunitinib plus gemcitabine versus sunitinib alone for sarcomatoid features.

Renal medullary Carcinoma is extremely rare with 6795\% having metastasis at presentation. Chemotherapy is the main focus of treatment.

Collecting duct carcinoma (CDC) is also rare with $40 \%$ patients with metastasis at presentation. Most die within 1-3 years of diagnosis. They share biological features with transitional cell carcinoma. Gemcitabine plus cisplatin/carboplatin has shown a response rate of $26 \%$ with an OS of 10.5 months.

\section{SORAFENIB FOR NON-CLEAR CELL RENAL CELL CARCINOMA}

It is no longer recommended for nccRCC. Similar to sunitinib, data indicate that compared with ccRCC, clinical activity of these drugs expressed seems to be reduced in patients with nccRCC.

The NCCN panel does not recommend sorafenib for patients with stage IV nccRCC.

\section{CONCLUSION}

Outcomes of patients with nccRCC have improved with the introduction of targeted therapy. Precise pathological diagnosis of the types of nccRCC by immunohistochemical analysis is mandatory. This enables specific treatments for individual nccRCC. Currently TKIs are the drug of choice (both first and second line) for metastatic papillary RCC. Both TKIs and mTOR inhibitors are effective against chromophobe RCC. Platinum based chemotherapy should be used for metastatic CDC. Further evidence is required for management of nccRCC.

Funding: No funding sources Conflict of interest: None declared Ethical approval: Not required

\section{REFERENCES}

1. Lee JL, Ahn JH, Lim HY, Park SH, Lee SH, Kim $\mathrm{TM}$, et al. Multicenter phase II study of sunitinib in patients with non-clear cell renal cell carcinoma. Ann Oncol. 2012;23:2108-14.

2. Choueiri TK, Plantade A, Elson P, Negrier S, Ravaud A, Oudard S, et al. Efficacy of sunitinib and sorafenib in metastatic papillary and chromophobe renal cell carcinoma. J Clin Oncol. 2008;26:127-31.

3. Armstrong AJ, Halabi S, Eisen T, Broderick S, Stadler WM, Jones RJ, et al. Everolimus versus sunitinib for patients with metastatic non-clear cell renal cell carcinoma (ASPEN): a multicentre, openlabel, randomised phase 2 trial. Lancet Oncol. 2016;17:378-88.

4. Tannir NM, Jonasch E, Albiges L, Altinmakas E, $\mathrm{Ng}$ CS, Matin SF, et al. Everolimus versus sunitinib prospective evaluation in metastatic non-clear cell renal cell carcinoma (ESPN): a randomized multicenter phase 2 trial. Eur Urol. 2016;69:866- 74.

5. Ciccarese C, Iacovelli R, Brunelli M, Massari F, Bimbatti D, Fantinel E, et al. Addressing the best treatment for non-clear cell renal cell carcinoma: a meta-analysis of randomised clinical trials comparing VEGFR-TKis versus mTORi-targeted therapies. Eur J Cancer. 2017;83:237-46.

6. Campbell MT, Bilen MA, Shah AY, Lemke E, Jonasch E, Venkatesan AM, et al. Cabozantinib for the treatment of patients with metastatic non-clear cell renal cell carcinoma: A retrospective analysis. Eur J Cancer. 2018;104:188-94.

7. Blank CU, Bono P, Larkin JMG, Gogov S, Panneerselvam A, Garay CA, et al. Safety and efficacy of everolimus in patients with non-clear cell renal cell carcinoma refractory to VEGFtargeted therapy: Subgroup analysis of REACT. J Clin Oncol. 2012;30 (5_suppl):402.

8. Koh Y, Lim HY, Ahn JH, Lee JL, Rha SY, Kim YJ, et al. Phase II trial of everolimus for the treatment of nonclear-cell renal cell carcinoma. Ann Oncol. 2013;24:1026-31.

9. Escudier B, Molinie V, Bracarda S, Maroto P, Szczylik C, Nathan P, et al. Open-label phase 2 trial of first-line everolimus monotherapy in patients with papillary metastatic renal cell carcinoma: RAPTOR final analysis. Eur J Cancer. 2016;69:22635.

10. Jung KS, Lee SJ, Park SH, Lee JL, Lee SH, Lim JY, et al. Pazopanib for the treatment of non-clear cell renal cell carcinoma: a single-arm, open-label, multicenter, phase II study. Cancer Res Treat. 2018;50:488-49.

11. Park I, Lee SH, Lee JL. A multicenter phase ii trial of axitinib in patients with recurrent or metastatic non-clear-cell renal cell carcinoma who had failed prior treatment with temsirolimus. Clin Genitourin Cancer. 2018;16:e997-e1002.

12. Irshad T, Olencki T, Zynger DL, Coston A, Mortazavi A, Monk JP. Bevacizumab in metastatic papillary renal cell carcinoma (PRCC). J Clin Oncol. 2011;29:e15158

13. Gordon MS, Hussey M, Nagle RB, Lara Jr PN, Mack PC, Dutcher J, et al. Phase II study of erlotinib in patients with locally advanced or metastatic papillary histology renal cell cancer: SWOG S0317. J Clin Oncol. 2009;27:5788-93.

14. Koshkin VS, Barata PC, Zhang T, George DJ, Atkins MB, Kelly WJ, et al. Clinical activity of nivolumab in patients with non-clear cell renal cell carcinoma. J Immunother Cancer. 2018;6:9. 
15. McKay RR, Bosse D, Xie W, Wankowicz SA, Flaifel A, Brandao R, et al. The clinical activity of PD-1/PD-L1 inhibitors in metastatic non-clear cell renal cell carcinoma. Cancer Immunol Res. 2018;6:758-65.

16. Srinivasan R, Su D, Stamatakis L, Siddiqui MM, Singer E, Shuch B, et al. Mechanism based targeted therapy for hereditary leiomyomatosis and renal cell cancer (HLRCC) and sporadic papillary renal cell carcinoma: interim results from a phase 2 study of bevacizumab and erlotinib. Eur J Cancer. 2014;50:8.

17. Voss MH, Molina AM, Chen YB, Woo KM, Chaim JL, Coskey DT, et al. Phase II trial and correlative genomic analysis of everolimus plus bevacizumab in advanced non- clear cell renal cell carcinoma. J Clin Oncol. 2016;34:3846-53.

18. Hudes G, Carducci M, Tomczak P, Dutcher J, Figlin $\mathrm{R}$, Kapoor A, et al. Temsirolimus, interferon alfa, or both for advanced renal-cell carcinoma. N Engl J Med. 2007;356:2271-81.

19. Dutcher JP, de Souza P, McDermott D, Figlin RA, Berkenblit A, Thiele A, et al. Effect of temsirolimus versus interferon-alpha on outcome of patients with advanced renal cell carcinoma of different tumor histologies. Med Oncol. 2009;26:202-9.

20. Venugopal B, Ansari J, Aitchison M, Tho LM, Campbell R, Jones RJ. Efficacy of temsirolimus in metastatic chromophobe renal cell carcinoma. BMC Urol. 2013;13:26.

Cite this article as: Sengupta S, Basu S, Ghosh K. Recent advances in the systemic management of nonclear cell renal cell carcinoma: a review article. Int $\mathbf{J}$ Adv Med 2020;7:1446-50. 